\title{
Intellectual Property Rights (IPRs), Competition Law and Excessive Pricing of Medicines
}

\author{
Mor Bakhoum
}

\section{Introduction}

This chapter wrestles with the interface between Intellectual Property Rights (IPRs), competition law and access to medicines. It emphasizes the important role that competition law may play, in addition to the internal IP flexibilities, in order to foster access and dissemination of medical products. Of course, competition law could also be considered as a flexibility within the TRIPS agreement. In our analysis, we consider competition law separately given its role in creating competitive markets within which IP products are commercialized. Relying on the recent case law in the EU, in Italy and in South Africa on the application of competition law in the pharmaceutical sector, with a focus on the prohibition of excessive pricing of pharmaceuticals, this paper argues that TRIPS flexibilities are an important regulatory tool to control prices and to foster access to medicines. However, in certain circumstances, IP flexibilities are operational only within a competitive market that is guaranteed by a functioning competition law.

Section 2 of the paper, which sets the stage, discusses the interface between TRIPS and Competition Policy and the enforcement orientation of competition law in the pharmaceutical sector since the entry into force of the TRIPS Agreement. This section presents the TRIPS competition-related provisions and their approach as a flexibility instrument. In addition to serving as a technology transfer instrument, ${ }^{1}$ TRIPS competition-related provisions may also be used in order to foster access to medicines. In this regard, this section emphasises the IP-related restrictions of

\footnotetext{
${ }^{1}$ See for discussion, Ullrich (2005), pp. 727-756.

M. Bakhoum ( $\square)$

UVS Doctoral School, Université Virtuelle du Sénégal (UVS), Dakar, Senegal

Max Planck Institute for Innovation and Competition, Munich, Germany

e-mail: mor.bakhoum@uvs.edu.sn 
competition in the pharmaceutical sector that can affect access to medicines. The discussion is informed by both the findings of the 2009 and 107 EU reports on the pharmaceutical sector and the case law on reverse payment settlements in the EU and the US.

Section 3 of the paper focuses on the recent trends of competition law enforcement in the pharmaceutical sector with the emerging case law on excessive (high) pricing of pharmaceuticals. The discussion is informed by the Aspen Case on excessive pricing decided by the Italian competition authority and the ongoing investigations against Aspen in the EU and in South Africa.

Section 4 deals with excessive pricing of pharmaceuticals in relations to IP flexibilities. It showcases that creating competitive pharmaceuticals markets by dealing with IP related restrictions of competition is in most cases important for TRIPS flexibilities to be operational. In addition to emphasizing the role of competition law enforcement as a complement to the TRIPS flexibilities, the section outlines situations where competition law enforcement is warranted.

Section 5 concludes with policy recommendation on how to align IP flexibilities and competition law enforcement in order to foster access to pharmaceuticals.

\section{TRIPS and Competition Policy: Orientations and Enforcement Trends in the Pharmaceutical Sector}

This section discusses three aspects: first, from a conceptual point of view, the interface between IP and Competition Law, second, TRIPS and Competition Policy with a reminder of TRIPS' approach to competition law and, third, the enforcement trends of competition law in the pharmaceutical sector since the entry into force of the TRIPS Agreement.

\subsection{The Interface Between IPRs and Competition Law}

The interplay between IP and competition law is dynamic. The IP system provides, in theory incentives for innovation and the development of cultural markets. However, IPRs do not operate in a vacuum. IPRs are exercised and commercialized in markets that are mostly regulated. As a market regulatory tool, competition law determines the framework within which IPRs are commercialized. However, the potential of competition law to serve as a market regulatory tool differs from country to country. Hence, competition law is still not implemented everywhere and in developing countries, strong enforcement is lacking. Competition law used to be approached as a regulatory instrument that limits the exercise of IPRs. This "conventional" and conflicting approach of the interface between IPRs and competition 
law is exemplified by the TRIPS competition-related provisions ${ }^{2}$ which are designed as a limit to the exercise of IPRs. This approach of the interface between IPRs and competition law is not in line with the approach of the relationship between IP and competition law as being complementary. ${ }^{3}$

The protection granted by the IP system to the right holders is not a reward as such. IP protection provides only to the right holder an opportunity to extract a reward from the market ${ }^{4}$ by commercializing its invention. The development and successful commercialisation of new technologies and products is closely related to the competitiveness of the markets within which they are commercialized. Hence, in most cases, the markets conditions determine whether a new technology is successful or not. With regards to the flexibilities within the IP system, building competitive markets is also a precondition for their operability. Of course, in complement to using competition law as a regulatory tool, using IP flexibilities participate to building competitive markets. Hence, as we shall see in this chapter, anticompetitive behaviours may hinder the build-in flexibilities of the IP system. With regards to access to pharmaceuticals, which is the focus of this paper, a number of anticompetitive behaviours (limitation of compulsory licensing, limitation of parallel import, or extension of the duration of the patent-reverse payment settlements) that affect the competitiveness of the pharmaceutical markets, and may affect the IP flexibilities that are crucial to access to pharmaceuticals.

\subsection{TRIPS and Competition Law: Competition Law as Flexibility Tool}

TRIPS is the first international instrument that recognizes the possibility to police the exercise of IPRS. TRIPS prohibits IPR-related restrictions of competition. Articles $8,31(\mathrm{k})$ and 40 of TRIPS, which are usually referred to as the TRIPS competitionrelated provisions, are largely conceived as legal tools to monitor the exercise of IPR (s) based on competition considerations. ${ }^{5}$ Competition law is part of the flexibility tools of the IP system. Competition related provisions within TRIPS are part of the general architecture of the Agreement and they provide a necessary balance to potential abusive exercise of IPRS. They should be read as part of the rights recognized to IP owner, and, also, their limits.

The competition-related provisions in the TRIPS were a result of a compromise between developed and developing countries during the negotiation of the TRIPS agreement. ${ }^{6}$ Developing countries which feared a monopolistic exercise of IPRs

\footnotetext{
${ }^{2}$ Which focus on technology transfer. See for discussion, Ullrich (2005), pp. 727-756.

${ }^{3}$ Bakhoum and Gallego (2016), p. 9, see specially reference in fn. 33 .

${ }^{4}$ See Ullrich and Heinemann (2007), p. 146.

${ }^{5}$ Bakhoum and Gallego (2016).

${ }^{6}$ Ullrich (2005), pp. 727-756.
} 
managed to have provisions on competition law included in order to mitigate potential abuses in the exercise of IPRs.

Initially, competition law in TRIPS was associated with technology transfer. ${ }^{7}$ In licensing agreements, competition law was considered as an instrument that protects the weaker licensee party against potential abuses of the IP right holder. As a consequence, TRIPS provides a detailed treatment of anticompetitive practises in licensing agreements. ${ }^{8}$

The reach of TRIPS competition related provisions is, however, not only limited to technology transfer. In additional to facilitating technology transfer, TRIPS competition related provisions can be read as an innovation policy tool. ${ }^{9}$

With regards to access to pharmaceuticals/medical products, TRIPS competitionrelated provisions may also be used as an access to medicines tool. This approach is proven by the increased reliance on competition law in the pharmaceutical industry since the entry into force of the TRIPS agreement. ${ }^{10}$ Competition enforcement is a complement to the IP flexibilities ${ }^{11}$ stricto sensu.

TRIPS does not create a binding international framework that obliges signatory members to apply competition law to IP-related restrictions of competition. The effectiveness of using competition law as a flexibility tool in the pharmaceutical sector depends on the institutional framework of each country. Unlike in IP law, there is no binding multilateral instrument that regulates competition law. ${ }^{12}$ The use of competition law as a flexibility tool is optional. Member States are given leeway to define their own policies when it comes to applying their competition law to IP-related restrictions.

This situation creates an imbalance from an international perspective. On the one hand, there is a harmonization, from the top, of the protection of IPRs. On the other hand, the use of competition law is 'deregulated' and left to the choice of each member to define its own policy. This "deregulation" of competition law enforcement has consequences, especially for developing countries, when applying competition law in the pharmaceutical sector.

\footnotetext{
${ }^{7}$ Ullrich (2005), pp. 727-756.

${ }^{8}$ Article 40 TRIPS reads: " 1 . Members agree that some licensing practices or conditions pertaining to intellectual property rights which restrain competition may have adverse effects on trade and may impede the transfer and dissemination of technology.

2. Nothing in this Agreement shall prevent Members from specifying in their legislation licensing practices or conditions that may in particular cases constitute an abuse of intellectual property rights having an adverse effect on competition in the relevant market. As provided above, a Member may adopt, consistently with the other provisions of this Agreement, appropriate measures to prevent or control such practices, which may include for example exclusive grantback conditions, conditions preventing challenges to validity and coercive package licensing, in the light of the relevant laws and regulations of that Member".

${ }^{9}$ Bakhoum and Gallego (2016).

${ }^{10}$ See infra, enforcement trends in the pharmaceuticals sector. See also, European Commission (2009-2017) https://ec.europa.eu/competition/sectors/pharmaceuticals/report2019/report_en.pdf.

${ }^{11}$ See, Berger (2006), p. 182.

${ }^{12}$ Drexl (2004), pp. 419-457.
} 


\subsection{Enforcement Trends of Competition Law in the Pharmaceutical Sector}

IPRs have expanded both in quantity and quality since the entry into force of the TRIPS agreement. New types of technologies, works and trademarks have been found eligible for protection; ${ }^{13}$ rights holders have been granted new exclusive prerogatives; ${ }^{14}$ the terms of protection for certain subject matter have been extended; ${ }^{15}$ and enforcement mechanisms and remedies have been strengthened and taken on an increasingly punitive character. ${ }^{16}$

From an international perspective, we notice a proliferation of the so-called TRIPS-Plus agreements through bilateral and regional trade agreements. As a result, standards of IPR protection of developed countries have been transferred to developing countries without due regard for the socio-economic, political and social context of the latter. ${ }^{17}$ This development reduces the policy space of developing countries to use TRIPS flexibilities, including in order to foster access to pharmaceuticals.

In reaction to the enhanced protection of IPRs through the TRIPS-Plus agreements there is a parallel push on how to best use the flexibilities embodied within TRIPS. The development in the framework of Doha with the Doha Declaration on IP and public health and subsequent article 31 bis, which took over a decade to be implemented, to allow WTO members to issue compulsory licenses for export are prime examples of this development. ${ }^{18}$ Parallel to harnessing the use of TRIPS flexibilities, competition law enforcement is increasingly taking place in developed countries with mature competition law system and in some developing countries South Africa is an example of a developing countries pushing for a proactive enforcement of competition law in the pharmaceutical sector.

Anticompetitive behaviours in the pharmaceutical sector may affect both innovation and access to medicines. The 2009 Pharmaceutical Sector Inquiry Report of the European Commission and the subsequent enforcement report of 2017 have

\footnotetext{
${ }^{13}$ See e.g. Directive 96/9/EC of the European Parliament and of the Council of 11 March 1996 on the legal protection of databases, OJ L 77, 27 March 1996, pp. 20-28.

${ }^{14}$ In the copyright field, for example, new forms of digital infringement related to the protection of technological protection measures have been created; see e.g. Directive 2001/29/EC of the European Parliament and of the Council of 22 May 2001 on the harmonization of certain aspects of copyright and related rights in the information society, OJ L 167, pp. 10-19.

${ }^{15}$ See e.g. Directive of the European Parliament and of the Council of 27 September 2011 amending Directive 2006/116/EC on the term of protection of copyright and certain related rights, OJ L 265, 11 October 2011, pp. 1-5; Sonny Bono Copyright Term Extension Act, Pub. L. No.105-298, 112 Stat. 2827 (1998).

${ }^{16}$ See e.g. Directive 2004/48/EC of the European Parliament and of the Council of 29 April 2004 on the enforcement of intellectual property rights, OJ L 195, 2 June 2004, pp. 16-25.

${ }^{17}$ For an overview and analysis of the most significant free trade agreements (FTAs) see Roffe (2014), pp. 17-40.

${ }^{18}$ Bakhoum and Gallego (2016).
} 
identified patenting strategies that block the development of competing medicines by reducing the incentives of other originator companies to continue their own R\&D efforts. ${ }^{19}$ With regards to access, patenting strategies may also delay competition by generics. ${ }^{20}$ In 2007, the European Commission started an investigation against Boehringer Ingelheim after a competing pharmaceutical company had raised concerns that Boehringer's patent applications would have the potential of blocking its competing medicines. The case was settled between the companies. ${ }^{21}$

Since the entry into force of the TRIPS agreement, there is an increased scrutiny by competition authorities of behaviours in the pharmaceutical sector that negatively impact the timely entry of generics. ${ }^{22}$ In the EU, since the publication of the sector inquiry report on the pharmaceutical sector in 2009 there is an increased scrutiny of these practises. $^{23}$

With regard to the interface between IP and Competition law, three different types of conducts may be identified: Category one concerns practices that are within the ambit of the patent system (Italian Pfizer, AstraZeneca) and involve the misuse of the patent and regulatory system which may impact innovation and access. Category two concerns behaviors that are outside of the boundaries of the patent system (such as ever-greening) while category 3 comprises practices half-way between the other two categories (pay for delay cases, FTC v Actavis, Lundbeck). ${ }^{24}$

\footnotetext{
${ }^{19}$ European Commission (2009), pp. 16 and 19. http://ec.europa.eu/competition/sectors/ pharmaceuticals/inquiry/staff_working_paper_part1.pdf.

Generally, the Sector Inquiry Report is concerned with two different sets of strategic patenting practices: on the one hand, those which aim at extending the exclusivity period to delay market entry of generics, and on the other hand, those whose objective is to block substitutive innovations by competitors. Regarding the later, blocking patents can be applied for either to broaden the applicant's own field of activity (defensive blocking patents) or to limit the scope of action of competitors (aggressive blocking patents); see Ullrich (2013), pp. 244 and 248.

${ }^{20}$ The Commission and the two European courts have confirmed the application of Article 102 of the Treaty on the Functioning of the European Union (TFEU) to a strategic use of patent procedures aimed at delaying generic entry in the Astra Zeneca case; see Commission Decision of 15 June 2005 relating to a proceeding under Article 82 of the EC Treaty and Article 54 of the EEA Agreement, Case COMP/A.37.507/F3 - Astra Zeneca, http://ec.europa.eu/competition/antitrust/cases/dec docs/37507/37507_193_6.pdf (accessed 23 October 2014); GC, Case T-321/05, Astra Zeneca v. Commission, [2010] ECR 2010 II-2805; CJ, Case C-457/10 P, Astra Zeneca v. Commission, [2012] ECR I-770. On the relevance of the Astra Zeneca rulings for the assessment of blocking patents see Drexl (2013), pp. 312 et seq.

${ }^{21}$ See European Commission, Press Release of 6 July 2011, IP/11/842. http://europa.eu/rapid/pressrelease_IP-11-842_en.htm.

${ }^{22}$ See the different cases discussed in this paper: See Case T-472/13, Lundbeck v. Commission, infra, box n ${ }^{\circ}$ 1; Case C-142/18, J\&J et al. vs. Commission ("Fentanyl"), infra, box $n^{\circ} 2$; Case U.S. Supreme Court No. 12-416, FTC v. Actavis, infra, box 3; Case T-691/14, Servier and others v. Commission (still pending).

${ }^{23}$ See Contribution by the European Commission, UNCTAD Roundtable on The Role of Competition in the Pharmaceutical Sector and its Benefits for Consumers. https://unctad.org/system/files/ non-official-document/CCPB_7RC2015_RTPharma_EC_en.pdf.

${ }^{24}$ Such distinction was made by Gallasch (2015). http://unctad.org/meetings/en/Presentation/ CCPB_7RC2015_PRES_RTPharma_Gallasch_en.pdf.
} 
In addition to "traditional" types of anticompetitive behaviours that affect pharmaceutical markets (cartels, bid rigging, and boycotts are conventional behaviours that aim to fix prices and earn monopoly profits), a particular type of anticompetitive agreement in the pharmaceutical industry has drawn the attention of competition law enforcers in recent years: the practice commonly known as a "pay for delay" agreement or, since it often involves a payment from the patentee to the alleged infringer, a "reverse payment" settlement agreement. Basically, it concerns situations where a brand-name pharmaceutical company, as patent holder, and a generic producer, agree to settle either a patent infringement suit or a dispute concerning the validity of the patent under terms that require, firstly, the generic manufacturer not to produce and/or to distribute the patented product until the expiration of the patent, and secondly, the patent holder to "compensate" the generic company for staying out of the market.

Both in the United States and in Europe, the competition agencies and national/ regional courts have perceived such arrangements as an attempt to allocate markets and preserve monopolistic conditions ${ }^{25}$ and have condemned them as clear violations of competition law. ${ }^{26}$ In the United States the Supreme Court has already had the opportunity to pronounce on the legal assessment of this kind of patent settlements. $^{27}$

In July 2013, the European Commission fined Lundbeck and several producers of generic medicines for delaying generic market entry of Citalopram. ${ }^{28}$ In December

\footnotetext{
${ }^{25}$ Announcing the Commission's decision on the Servier case, then Competition Commissioner Joaquín Almunia stated "Servier had a strategy to systematically buy out any competitive threats to make sure that they stayed out of the market. Such behavior is clearly anti-competitive and abusive. Competitors cannot agree to share markets or market rents instead of competing, even when these agreements are in the form of patent settlements. Such practices directly harm patients, national health systems and taxpayers". See European Commission, Press Release of 9 July 2014, IP/14/799. http://europa.eu/rapid/press-release_IP-14-799_en.htm.

${ }^{26}$ In Europe, see European Commission, Press Release of 19 June 2013, IP/13/563 (Antitrust: Commission fines Lundbeck and other pharma companies for delaying market entry of generic medicines). http://europa.eu/rapid/press-release_IP-13-563_en.htm?locale=en; Press Release of 10 December 2013, IP/13/1233 (Antitrust: Commission fines Johnson \& Johnson and Novartis $€$ 16 million for delaying market entry of generic pain-killer fentanyl). http://europa.eu/rapid/pressrelease_IP-13-1233_en.htm; Press Release of 9 July 2014, IP/14/799 (Antitrust: Commission fines Servier and five generic companies for curbing entry of cheaper versions of cardiovascular medicine). http://europa.eu/rapid/press-release_IP-14-799_en.htm. All press releases accessed 23 October 2014. At the time of writing this contribution, no public version of these decisions was yet available. For an overview of the FTC's practice see Cook (2001), pp. 437 et seq. (commenting particularly on In re Schering-Plough Corp., 136 F.T.C. 956 (2003); FTC v. Watson Pharm., Inc., 611 F. Supp. 2d 1081 (C.D. Cal. 2009) and FTC v. Cephalon, Inc., 551 F. Supp 2d 21 (D.D.C. 2008)).

${ }^{27}$ See Actavis decision.

${ }^{28}$ Press release Commission: http://europa.eu/rapid/press-release_IP-13-563_en.htm?locale=en Information of General Court upon time of completion not available (July 2015).
} 
2013, the Commission fined Novartis and $\mathbf{J} \& \mathrm{~J}^{29}$ which concluded an agreement whose aim was to delay the market entry of cheaper generic version of Fentanyl, a painkiller. This was a straightforward pay-for-delay case as it did not involve any patent dispute or litigation.

In the US, the Actavis decision of the Supreme Court ${ }^{30}$ sets the legal standard for the appreciation of pay-for-delay cases. After a discrepancy of decisions from lower courts, the Supreme Court concluded that the rule of reason should be applied to reverse payment settlements.

\section{Excessive Pricing of Pharmaceuticals: An Emerging Enforcement Trend}

Three aspects are discussed in this section: first, pricing of pharmaceuticals and IPRs, second, the case law on excessive pricing, third, the competition related issues raised by the case law on excessive pricing.

\subsection{Pricing of Pharmaceuticals and IPRs}

IPRs affect the pricing of pharmaceuticals. The IP system has two dimensions: On the one hand, it regulates the conditions of acquisition of IPRs. On the other hand, it allows the right holder to exercise the exclusivity of the right conferred, by, for instance setting a given price for IP embodied products such as pharmaceuticals. Hence, an important right of IPRs holders is the freedom of pricing of IP embodied products. Freedom of pricing of pharmaceuticals is part of the exclusivity the IPRs holder enjoys. However, freedom of pricing pharmaceutical, as a right, is not absolute. It should be exercised in accordance with the principles of the market. Hence, pricing of pharmaceuticals should not be anticompetitive.

From a competition law perspective, a core principle of the market economy and competition is the freedom of the pharmaceutical companies to set the prices of their products. Freedom of pricing pharmaceuticals is an expression of the general freedom of contract (freedom to enter into business dealings) which also is a tenet of the market economy. ${ }^{31}$ When an IPR is involved, contractual freedom may be exercised through licensing agreements. Sometimes, as part of the general IP policy

\footnotetext{
${ }^{29}$ See press release of Commission: http://europa.eu/rapid/press-release_IP-13-1233_en.htm; full text of judgment available at http://ec.europa.eu/competition/antitrust/cases/dec_docs/39685/ 39685_1976_7.pdf.

${ }^{30} 570$ U.S. 133 S. Ct. 2233 (2013). Judgment of the US Supreme Court available at: http://www. supremecourt.gov/opinions/12pdf/12-416_m5n0.pdf.

${ }^{31}$ For discussion on freedom of contract and competition law, see, Bakhoum (2018), pp. 157-186.
} 
and the need to prevent potential abuse exercise of IPRs, freedom of contract, and of pricing, may be limited in order to protect the competitiveness of the markets and consumers. Contractual freedom and the freedom to set prices should not lead to anticompetitive practices that could take a form of high pricing of pharmaceuticals. High pricing is considered, in some competition law, as a form of abuse of dominant position.

\subsection{Overview of the Case Law on Excessive Pricing of Pharmaceuticals}

Excessive pricing is considered a type of abuse of dominant position in number of jurisdictions. This is the case in the EU and some of its Member States. In South Africa also high pricing is considered an abuse of dominant position. If in principle, this form of prohibition is recognized, in practice, competition authorities have been very reluctant in dealing with excessive pricing cases.

Recently, however, high pricing of pharmaceuticals has attracted the attention of competition authorities with a number of cases in the UK, the EU and in South Africa. In the EU, the Aspen case on excessive pricing decided by the Italian Competition Authority has attracted significant attention. Ongoing investigations both in the EU and in South Africa illustrate what could be considered as an emerging enforcement trend on the application of competition law in the pharmaceutical sector.

The Italian Aspen case illustrates how important it is to have competitive markets in order to make TRIPS flexibilities operational. In this case, the Italian Competition Authority fined Aspen for infringing Article 102 (a) of the TFEU. The Italian Competition Authority considered that Aspen "had fixed unfair prices with increases up to $1500 \%$ ". ${ }^{32}$ It results from the facts that Aspen had acquired an off-patent cancer drug package from GlaxoSmithKline. The antitumor drugs are considered life-saving and irreplaceable especially in the treatment of children and elderly patients.

After acquiring the rights on the drugs, Aspen initiated "negotiations with the Italian Medicines Agency (Agenzia Italiana del Farmaco - AIFA) with the sole aim to obtain a high increase in prices, even in the absence of any necessary economic justifications". ${ }^{33}$ An important factual element in the Aspen case is that there was a public procurement with the authorities purchasing directly the drugs from Aspen. Aspen used aggressive negotiation strategy with the Italian Medicines Agency and

\footnotetext{
${ }^{32}$ See Press release on the Aspen case, 14/10/2016, available at: http://www.agcm.it/en/newsroom/ press-releases/2339-a480-price-increases-for-cancer-drugs-up-to-1500-the-ica-imposes-a-5-mil lion-euro-fine-on-the-multinational-aspen.html. For discussion of the case, see also, Lanza and Sfasciotti (2018), pp. 382-388.

${ }^{33}$ See Press release on the Aspen case, op. cit.
} 
threaten to interrupt supply to the Italian market. ${ }^{34}$ As a consequence of its negotiation strategy Aspen obtained extremely high prices ranging between $300 \%$ and $1500 \%$ of the initial levels. ${ }^{35}$

Two aspects were considered by the Italian Competition Authority when assessing the excessiveness of the prices charged by Aspen. It first considered the disproportion between price and cost. Second, it considered additional aspects such as the "specific context and behavioural factors, such as: the inter-temporal comparison of prices, the absence of economic justifications for the increase, the absence of any extra-economic benefits for patients, the nature of Comos's drugs, the characteristics of the Aspen group, and the damage caused to the National Health System (Sistema Sanitario Nazionale - SSN)".36

Similar investigations on excessive pricing have been opened by other competition authorities. In 2017 the EU Commission opened its first formal investigation on excessive pricing against Aspen for life saving cancer medicines. ${ }^{37}$ The facts of the ongoing case are the same as the facts in the Aspen Italian case. The medicines in question were off-patent and Aspen acquired them after their patents had expired. As in the Italian case, "Aspen has imposed very significant and unjustified prices increases of up to several hundred percent (...)". ${ }^{38}$ Moreover, "Aspen has threatened to withdraw the medicines in question in some Member States and has actually done so in certain cases". 39

In the UK, the Competition and Markets Authority (CMA) in 2016 fined Pfizer, Inc. (Pfizer) and Flynn Pharma Limited (Flynn) for charging excessive price for an anti-seizure drug. The CMA found that both Pfizer and Flynn were dominant in their respective markets of manufacturing and distribution of Epanutin and had significantly improved their cost-profit margins by increasing the sale price by $2600 \%$.

In South Africa, the South African Competition Authority had opened investigations against Roche, Pfizer and Aspen on high pricing. ${ }^{40}$ The Commission mentioned that Roche has and "continue[s] to engage in excessive pricing, price discrimination and/or exclusionary conduct in the provision of breast cancer medicine in South Africa". ${ }^{41}$ The Commission added that "as a result of exorbitant

\footnotetext{
${ }^{34}$ See Press release on the Aspen case, op. cit.

${ }^{35}$ See Press release on the Aspen case, op. cit.

${ }^{36}$ See Press release on the Aspen case, op. cit.

${ }^{37}$ European Commission, Press Release, Antitrust: Commission opens formal investigation into Aspen Pharma's pricing practices for cancer medicines, May 15, 2017, http://europa.eu/rapid/pressrelease_IP-17-1323_en.htm.

${ }^{38}$ May 2017 European Commission, Press Release, Antitrust: Commission opens formal investigation into Aspen Pharma's pricing practices for cancer medicines, May 15, 2017.

${ }^{39}$ May 2017 European Commission, Press Release, Antitrust: Commission opens formal investigation into Aspen Pharma's pricing practices for cancer medicines, May 15, 2017.

${ }^{40}$ Media release, South African Competition Commission, 13 June 2017, available at: http://www. compcom.co.za/wp-content/uploads/2017/01/International-pharmaceutical-companies-investi gated-for-cancer-medicine-prices.pdf.

${ }^{41}$ Media release, South African Competition Commission, 13 June 2017, op. cit.
} 
prices, most breast cancer patients in both the private and the public sectors are unable to get treatment". ${ }^{42}$ The investigation against Pfizer relates also to excessive pricing of lung cancer medication. According to the Commission, "Pfizer is the only provider of lung cancer treatment medication known as xalkori crizotinib in South Africa" ${ }^{43}$ The investigation seems to be based on the fact that lung cancer treatment is unaffordable in South Africa given the high prices that the consumers are unable to afford. A Parallel investigation to the ongoing investigation in the EU is open against Aspen. The Investigation is based on a "reasonable suspicion that Aspen has and continues to engage in excessive pricing in the provision of certain cancer medicines (...)". 44

In the context of South Africa, the open investigations are in line with the earlier trend of the Commission to investigate anticompetitive practices in the pharmaceutical sector. A complaint was lodged before the South African Competition Commission against GlaxoSmithKline South Africa (Pty) Ltd ("GSK") \& Boehringer Ingelheim (Pty) ("BI"), ${ }^{45}$ (hereinafter GSK/BI case), initially for high pricing, but then the Commission extended the investigation to include an alleged violation of Section $8(\mathrm{~b})$ and (c) of the Competition Act, which deals respectively with the essential facilities doctrine and exclusionary conduct. ${ }^{46}$ The Competition Commission concluded its investigation with a finding that GSK and BI abused their dominant position by charging excessive prices, refusing to grant access to essential facilities to a competitor and engaging in exclusionary conduct. The matter did not come before the Competition Tribunal, as GSK and BI accepted a settlement, which resulted in a drastic reduction in the prices of the pharmaceuticals in South Africa.

What can be learned from the Aspen Italian case and the ongoing investigations on excessive pricing of pharmaceuticals?

\subsection{Competition and IP Issues Raised by the Case Law on Excessing Pricing of Pharmaceuticals}

A number of lessons can be learned from the case law on excessive pricing of pharmaceuticals. There is an IP dimension and a competition law dimension in the analysis.

\footnotetext{
${ }^{42}$ Media release, South African Competition Commission, 13 June 2017, op. cit.

${ }^{43}$ Media release, South African Competition Commission, 13 June 2017, op. cit.

${ }^{44}$ Media release, South African Competition Commission, 13 June 2017, op. cit.

${ }^{45}$ The case was settled. For discussion of the background of the case, see, Berger (2004), pp. 197-201. The Commission's comments on the case at: South African Competition Commission Newsletter, edition.15, pp. 1-2. http://www.compcom.co.za/assets/Uploads/AttachedFiles/ MyDocuments/March-04-Newsletter.pdf.

${ }^{46}$ For a discussion of the case, see Ngobese and Mncube (2011).
} 


\subsubsection{IP, Patent Term and Excessive Pricing of Pharmaceuticals}

The case law on excessive pricing raises a number of issues that question the rationale of the IP system regarding access to pharmaceuticals.

The Italian Aspen case is not about IPRs and an abuse of a monopoly by a right holder during the protection term. It is true that pharmaceuticals are involved in the case. However, the pharmaceuticals patents for the cancer drugs had already expired when Aspen acquired them. As a consequence, IPRs cannot be invoked in order to justify the high prices charged by Aspen. The rationale of the IP system according to which the right holder has the exclusivity to commercialize its products at "monopoly price" is not applicable in this case. Aspen had acquired the pharmaceuticals at the end of the protection period. At the end of the exclusivity term, Aspen could still charge prices that are even higher than the prices of the pharmaceuticals when the patents were into force. The behavior of Aspen contradicts the very rationale of the IP system according to which price competition by generics should, in principle, drive the prices of pharmaceuticals down. Hence, at the end of the patent term, the rationale of the IP system that generic competition should take place and drive the prices down is not operational in this case. This is an important aspect of the Aspen Italian case. In Fact, the prices of the pharmaceuticals when the patents were in force were lower than the prices charged by Aspen when the drugs were off-patent.

Price competition by generics does not necessarily follow the end of the exclusivity period. For price competition by generics to take place the market conditions have to be attractive enough for generic companies to enter the market at the end of the patent term. If there is not price competition at the end of the exclusivity period, the patent holder still can charge high prices.

Another important element of the analysis is that the drugs had not been developed by Aspen. The usual justification of the recognition of the right of the IP holder to charge high prices is the investment made for the development of the IP embodied product. In this case, this rationale does not justify the high prices charged postpatent term. In fact, in the Italian Aspen case, the cancer drugs are produced by third party companies without any mobilization of resources by Aspen. To the contrary, the production costs of the medicines have considerably decreased over time. ${ }^{47}$ The increase of prices could not be justified by any costs since Aspen did not make any additional investment nor did it face any increase of production costs. Aspen did not make any improvement on the medicines and their related services. ${ }^{48}$

\footnotetext{
${ }^{47}$ See Lanza and Sfasciotti (2018), p. 386.

${ }^{48}$ Ibid.
} 


\title{
3.3.2 Competition Law and Excessive Pricing of Pharmaceuticals: Market Conditions and Pricing
}

\author{
Market Power, Size of the Market and High Pricing
}

The structure of a given market and its competitive conditions influence prices. If a market is open with low entry barriers and substitute products or services are available, there is a likelihood that the prices become competitive. If to the contrary, a market is very small, only one undertaking offers a service or product, and there is no substitute, there is a likelihood to have dominance and market power which allow the undertaking to charge high prices. In pharmaceuticals markets, this may happen even for off-patent drugs. In the Aspen case, for example, the small size of the market of the pharmaceuticals involved afforded Aspen market power and allowed it to charge high prices. Blood cancer drugs in the case "has a small incidence on the population and the specific categories of patients treated with Aspen's drugs further restrict the market size". ${ }^{49}$ The small size of the market for blood cancer drug afforded Aspen sufficient power to bargain for high prices with the Italian Medicines Agency. Aspen's market power allowed it to charge high prices without fear of losing market shares. Compared to the prices of the pharmaceuticals when the patents were in force, the prices increased from $300 \%$ to $1500 \%$. The prices of the patented medicine were more affordable than the prices of the same medicine off-patent. This price increase was only possible because the market was not competitive and Aspen did not face any competition constraints that obliged it to reduce its prices.

Market power allows an undertaking to behave into the market without taking into account actual or potential competition. It allows, for instance, an undertaking to set prices without fear of losing market share. The negotiation strategy adopted by Aspen confirms its market power. Using its market power, Aspen adopted an aggressive negotiation strategy and threatened to interrupt the supply of the Italian market. ${ }^{50}$ Aspen was able to use its superior bargaining power since it has market power and did not face any competition. As pointed out, "the absence of any medical alternative for the cure of the weakest fringe of patients made them non-substitutable (essential) for the NHS, thereby depressing AIFA's bargaining power in the negotiation with the company". ${ }^{51}$

\section{Absence of Substitutability and High Pricing of Pharmaceuticals}

The concept of substitutability is used in competition law analysis in order to determine whether two products or services belong to the same market. It allows

\footnotetext{
${ }^{49}$ Ibid.

${ }^{50}$ Ibid.

${ }^{51}$ Lanza and Sfasciotti (2018), p. 386.
} 
the competition authorities to define the relevant market and thereby determine whether a given undertaking enjoys a dominant position. If a market is small and there is no substitute for a given product, there is a strong likelihood that the undertaking offering the product will be found dominant. However, as a reminder, the simple fact of being dominant is not prohibited. Only abusive behavior resulting from a dominant position, such as charging excessive prices, is prohibited.

In the Aspen Italian case, Aspen's market power was reinforced by the absence of alternative medicines in the market. Hence, no substitutable drugs existed in the market for the category of patients in Aspen's market. This absence of substitutability of Aspen's pharmaceuticals limit the ability of the consumers to turn to substitute products when prices become high. No substitute existed for the pharmaceuticals involved in the case which are used to treat severe oncological diseases for children and elderly people. In other words, consumers could not shift to alternative pharmaceuticals that have similar therapeutic virtues when the prices become high. Given the absence of substitute pharmaceuticals, the Italian Medical Agency did not have a choice but to accept the prices charged by Aspen.

\section{Consumer Choice/Behavior (Rationality) and the Specificity of Pharmaceuticals}

What has been termed as "consumer rationality" 52 is also an element to be considered when pharmaceuticals are involved in a given case. Hence, if life saving drugs are involved, consumer behavior may be different. For life saving pharmaceuticals, in the absence of alternative drugs, consumers have a strong willingness to pay, no matter how high the prices are. Consumer rationality that commands consumers to seek alternative, more affordable, sources of supply when prices become high is not strong in the case of pharmaceuticals. If life saving drugs are involved, and there is no substitute, consumer rationality becomes absent.

From a contract law perspective, an argument can be made that since consumers are willing to pay competition authorities should not intervene in the contract relationships. However, the absence of substitute medicines and the uneven bargaining powers ${ }^{53}$ between consumers and Aspen, which has market power, should limit the freedom of contract.

The combined factors which are Aspen's market power, the lack of alternative products (substitute) and the absence of consumer rationality allowed Aspen to impose high prices on consumers.

\footnotetext{
${ }^{52}$ Ibid.

${ }^{53}$ For discussion on freedom of contract and competition law, see, Bakhoum (2018).
} 
The Issue of the Determination of an Excessive Price

Competition authorities have been very reluctant to deal with excessive pricing given the issues raised by the assessment of high pricing. What amounts to an excessive price is a first hurdle that makes competition law intervention difficult. Whether dealing with excessive pricing is a form of regulation by competition authorities is another issue. By dealing with excessive pricing, competition authorities can be seen as price regulators. Regulating prices is not in principle the role of competition authorities. If from a theoretical point of view dealing with excessive pricing raises a number of issues, a number of competition laws still consider high pricing as a form of abuse of dominant position. A firm with a dominant position may charge excessive prices without the risk of market entry of competitors and thus without the risk of competition. How to determine high prices? What is the relation between the economic value of a product or service and high prices?

Excessive pricing may be assessed in relation to costs. In the Aspen case, the Italian Competition Authority applied the following method:

- An estimation of excessiveness based on "percentage gross margin"

- A profitability analysis - based on an approximation of the economic value of the drugs which takes into account all overall costs of making and commercializing the drug — compared to actual prices charged. ${ }^{54}$

The cost price analysis was the main approach of the Italian Competition Authority in determining excessive pricing: As pointed out, "ICA's investigation on the unfair practice was carried out through a two-phase test that measured the disproportion between prices and costs. The unreasonableness of the mentioned disproportion resulted indicative of unfair prices also in the light of specific context and behavioural factors, such as: the inter-temporal comparison of prices, the absence of economic justifications for the increase, the absence of any extra-economic benefits for patients, the nature of Comos's drugs, the characteristics of the group Aspen and the damage caused to the National Health System (Sistema Sanitario Nazionale - SSN)", 55

Although Aspen did not incur any additional costs, it has substantially increased the prices. As indicated, there was "no investment to be recovered, no risk assumption by Aspen, no dry hole; no owned production facility, no freeze of financial resources by Aspen; no need to promote the drugs, no promotional costs to be recovered; no actual competitor, due to the absence of substitutability". "From a cost perspective, Aspen did not bring forth additional arguments that justify the increase of prices.

\footnotetext{
${ }^{54}$ See, Lanza and Sfasciotti (2018), p. 385.

${ }^{55}$ See Press release on the Aspen case, op. cit.

${ }^{56}$ See, Lanza and Sfasciotti (2018).
} 


\section{Excessive Pricing of Pharmaceuticals and TRIPS Flexibilities: Lessons from the Excessive Prices Cases}

A number of lessons can be learned from the case law on excessive pricing, especially the Italian Aspen case in relation to the rationale of the IP system and Competition law as a flexibility tool.

Although pharmaceuticals were involved in the Aspen case, one can argue that the case raised only competition law issues. Since the patents of the cancer drugs involved in the Aspen case had already entered the public domain when Aspen acquired them, the behavior of Aspen could not be considered as an abuse of IPRs. The exclusivity afforded to the right holder of the pharmaceuticals ended with the patent term. The subsequent price increase at the end of the patent period could not, in principle, be considered an abuse of IPRs since the patented pharmaceutical has entered the public domain. However, in practice, the right holder of the off-patent pharmaceuticals continued to enjoy a de facto exclusivity and was able to charge high prices. Hence, although the pharmaceuticals involved in the Aspen case were no longer patented, the prices were not reduced. Such situation is not in line with the very rationale of the IP system according to which at the end of the patent term generic competition should kick in and drive the prices down. Similar to the reverse payment settlement cases that delay the entry in the market of generics, an abuse of dominant position post patent term may also slow the competition by generics.

Price reduction of pharmaceuticals is not automatic at the end of the patent term. There is a close link between the competitiveness of the market post patent and the reduction of prices at the end of the patent term. Whether prices of pharmaceuticals would be reduced at the end of the exclusivity period depends on the competitiveness of the market. If the market is open and competitive at the end of the exclusivity period with a possibility of entry of generics, prices may be reduced. However, generic entry is not automatic either. Generic entry takes place only if the market is attractive and that there is a strong likelihood to have return on investment. In the Italian Aspen case, there was no competition by generics despite the absence of patents attached to the drugs. Absent generic competition, the right holder continues to enjoy a de facto exclusivity and to be able to charge high prices. If a given market is small enough so that a pharmaceutical company enjoys a monopoly position, it can continue to charge excessive prices even at the end of the exclusivity period.

Substitutability and consumer choice are important for price reduction of pharmaceuticals to take place. Absence of substitute and consumer choice, a patent owner may continue to have market power and to charge high prices at the end of the patent protection. This is a de facto extension of the exclusivity rights. Patent protection does not necessarily create market dominance. However, market dominance may exist after the expiration of the exclusivity period if there is no competition in the market. Under certain market conditions at the expiration of the exclusivity period (market power, absence of substitute, no generic competition, price inelasticity, strong willingness of consumers to pay) the IP owner may still charge monopoly prices without fear of losing market shares. 
The Aspen case showcases how important it is to create competitive markets and to protect/promote competition in pharmaceuticals markets through a strong competition law enforcement. When IP flexibilities and the very rationale of the IP system are not operational at the end of the exclusivity period, competition law can be used as a tool to correct the anticompetitive behavior and to complement the IP system. As already pointed out, the design of TRIPS which have a competition law dimension as a flexibility tool gives to Member States the possibility to create strong competition law institutions in complement to the IP related flexibilities stricto sensu.

It also results from the Aspen case that under certain circumstances, access is more guaranteed (and prices are lower) during the exclusivity period, when the patent is still into force. This is the case when the flexibilities are fully applicable during the exclusivity period. It is possible during the patent term to use the flexibilities of the IP system such as issuing compulsory licenses. This possibility does not exist at the end of the exclusivity period.

There is a close link between the operability of the rationale of the IP system and its flexibilities and the market conditions. As highlighted in the discussion in this paper, having competitive markets participate to the operability of the core principles of the IP system and its flexibilities.

\section{Conclusions}

Competition law enforcement is a complement of the IP system and its flexibilities. IP and competition law are two regulatory instruments that both have their potential and limits. IP affords rights. Competition law defines the framework for the commercialization. The freedom of IP owners to determine the price of pharmaceuticals should be exercised while respecting the market (competition) rules.

The IP system and its flexibilities of the IP system have intrinsic limitations that affect their operability. They may not, in some situations, have the expected effect on access to pharmaceuticals. The Doha declaration and article 31 bis of the TRIPS agreements illustrate the difficulties to use the IP system in order to foster access to pharmaceuticals. There exist also some limits related to the scope of the IP system and its flexibilities. The IP system does not address the behavior of right holders that may affect prices of pharmaceuticals after the expiration of the patent term. Post patent term abusive behavior are beyond the reach of the IP system. In such situations, as illustrated by the Aspen case, only competition law may help reinstate the balance of the IP system.

The scope of application of competition law is more extended than the application of the IP flexibilities. Competition law polices the behaviors of market participants. It addresses practices when IPRs are into force and at the end of the protection term. Competition law is applicable when patented and off-patent products are involved such as in the Aspen case. Competition authorities are required to evidence a clear breach of the rules of the markets (e.g. cartels, abuse of dominance) and a clear 
framework of analysis is provided by the law. The evolution of competition enforcement in the pharmaceuticals sector since the entry into force of the TRIPS agreement has illustrated an evolutive approach that could have a positive impact of competition law enforcement on access to pharmaceuticals. The cases discussed in the UE, in Italy and in South Africa illustrate this trend to use a proactive role of competition law as an access to pharmaceuticals tools.

But competition law application in the pharmaceuticals sector is not without its issues: enforcement of competition law to IP related restrictions may be problematic. Hence, an argument can be made that strong enforcement may chill investment in R\&D and innovation. However, in addition to access, competition law takes into account the innovation parameters when applied to IP related restrictions. With regards to pharmaceuticals patents, the question of the balance between access and innovation raises issues. Can lower prices of pharmaceuticals (access) and innovation (bringing new pharmaceuticals into the market) be aligned? Does one want lower prices of pharmaceuticals or is innovation more important?

In cases involving charging high prices post patent term, as it was the case in Aspen, the innovation argument cannot be strongly supported. One could argue that in post patent term cases, after the expiration of the patent, the incentives to innovate argument should not be considered since the exclusivity rights have expired. The patent holder has already reaped the benefits and rewards of the invention. However, one also should take account of the argument that even after the expiration of the patent, strong enforcement of competition law and regulation of prices may affect $\mathrm{R} \& \mathrm{D}$ incentives.

Four different situations can be contemplated:

- If the flexibilities within the IP system work and may be used in order to enable the reduction of prices, one could consider that there may not be an access problem even if IP protection exists.

- IP flexibilities may work but anticompetitive conduct restricts their positive impact on prices and access. If for instance IP flexibilities are not operational because of anticompetitive practices, one could argue that there is a case for competition law intervention.

- If IP flexibilities do not work the question arises as to whether there is a case for competition law to correct the shortcomings.

- No IP flexibilities because IP protection expired: one could argue that there is a case also for competition law intervention as illustrated by the Aspen case. IPRs could no longer be an obstacle to competition law intervention.

The discussions of the paper is largely based on the case law in developed jurisdictions. However, developing and LDC countries can learn a lot from the approach of developed countries of using competition law as an external flexibility in order to foster access to medicine during the patent term and after the expiration of the patent. South Africa is making efforts in that direction. Developing countries with limited competition culture and resources still face the challenge of enforcing their competition law to restrictions of competition affecting access to medicines. Though the lack of challenges is an issue, it is crucial for policy makers and enforcer 
to encourage the application of competition law in the pharmaceutical sector in combination to the TRIPS flexibilities.

\section{References}

570 U.S. 133 S. Ct. 2233 (2013). Judgment of the US Supreme Court available at: http://www. supremecourt.gov/opinions/12pdf/12-416_m5n0.pdf. Accessed 24 Feb 2021

Bakhoum M (2018) Abuse without dominance in competition law: abuse of economic dependence and its interface with abuse of dominance. In: Di Porto F, Podszun R (eds) Abusive practices in competition law (ASCOLA Competition Law series). Edward Elgar Publishing, Cheltenham, UK; Northampton, MA, USA, pp 157-186

Bakhoum M, Gallego BC (2016) TRIPS and competition rules: from transfer of technology to innovation policy. In: Ullrich H, Hilty RM, Lamping M, Drexl J (eds) TRIPS plus 20 - from trade rules to market principles, $\mathrm{p} 9$

Berger J (2004) Advancing public health by other means: using competition policy, pp 197-201

Berger J (2006) Advancing public health by other means: using competition policy. In: Roffe P, Tansey G, Vivas-Eugui D (eds) Negotiating health: intellectual property and access to medicine. Earthscan, London, p 182

Case T-472/13, Lundbeck v. Commission, infra, box $\mathrm{n}^{\circ} 1$; Case C-142/18, J\&J et al. vs. Commission ("Fentanyl"), infra, box n 2; Case U.S. Supreme Court No. 12-416, FTC v. Actavis, infra, box 3

Case T-691/14, Servier and others v. Commission (still pending)

Cook A (2001) Pharmaceutical patent litigation settlements: balancing patent \& antitrust policy through institutional choice. Mich Telecommun Technol Law Rev 17(2):417-458

Directive 2001/29/EC of the European Parliament and of the Council of 22 May 2001 on the harmonization of certain aspects of copyright and related rights in the information society, OJ L 167, pp 10-19

Directive 2004/48/EC of the European Parliament and of the Council of 29 April 2004 on the enforcement of intellectual property rights, OJ L 195, 2 June 2004, pp 16-25

Directive 96/9/EC of the European Parliament and of the Council of 11 March 1996 on the legal protection of databases, OJ L 77, 27 March 1996, pp 20-28

Directive of the European Parliament and of the Council of 27 September 2011 amending Directive 2006/116/EC on the term of protection of copyright and certain related rights, OJ L 265, 11 October 2011, pp. 1-5; Sonny Bono Copyright Term Extension Act, Pub. L. No.105-298, 112 Stat. 2827 (1998)

Drexl J (2004) International competition policy after Cancún: placing a Singapore issue on the WTO development agenda. World Compet 27(3):419-457

Drexl J (2013) Astra Zeneca and the EU sector inquiry: when do filings violate competition law? In: Drexl J, Lee N (eds) Pharmaceutical innovation, competition and patent law - a trilateral perspective. Edward Elgar, Cheltenham, pp 290-322

European Commission (2009) Pharmaceutical Sector Inquiry - Final Report. http://ec.europa.eu/ competition/sectors/pharmaceuticals/inquiry/staff_working_paper_part1.pdf. Accessed $24 \mathrm{Feb}$ 2021, pp 16 and 19

European Commission, Competition enforcement in the pharmaceutical sector (2009-2017), available at: https://ec.europa.eu/competition/sectors/pharmaceuticals/report2019/report_en.pdf

European Commission, Antitrust: Commission welcomes improved market entry for lung disease treatments. Press Release of 6 July 2011, IP/11/842. http://europa.eu/rapid/press-release_IP-11842_en.htm. Accessed 24 Feb 2021

European Commission, Press Release, Antitrust: Commission opens formal investigation into Aspen Pharma's pricing practices for cancer medicines, 15 May 2017. http://europa.eu/rapid/ press-release_IP-17-1323_en.htm. Accessed 24 Feb 2021 
European Commission, Press Release of 10 December 2013, IP/13/1233 (Antitrust: Commission fines Johnson \& Johnson and Novartis $€ 16$ million for delaying market entry of generic painkiller fentanyl). http://europa.eu/rapid/press-release_IP-13-1233_en.htm. Accessed 24 Feb 2021

European Commission, Press Release of 19 June 2013, IP/13/563 (Antitrust: Commission fines Lundbeck and other pharma companies for delaying market entry of generic medicines). http:// europa.eu/rapid/press-release_IP-13-563_en.htm?locale=en. Accessed 24 Feb 2021

European Commission, Press Release of 9 July 2014, IP/14/799 (Antitrust: Commission fines Servier and five generic companies for curbing entry of cheaper versions of cardiovascular medicine). http://europa.eu/rapid/press-release_IP-14-799_en.htm. Accessed 24 Feb 2021

Gallasch S (2015) Pharmaceutical antitrust: use but with caution, contribution Keynote Speech at UNCTAD Roundtable on The Role of Competition in the Pharmaceutical Sector and its Benefits for Consumers, 8 July 2015 http://unctad.org/meetings/en/Presentation/CCPB_7RC2015_ PRES_RTPharma_Gallasch_en.pdf. Accessed 24 Feb 2021

Lanza EM, Sfasciotti PR (2018) Excessive price abuses: the Italian Aspen case. J Eur Compet Law Pract 9(6):382-388

Media release, South African Competition Commission, 13 June 2017., available at: http://www. compcom.co.za/wp-content/uploads/2017/01/International-pharmaceutical-companies-investi gated-for-cancer-medicine-prices.pdf

Ngobese M, Mncube L (2011) Competition policy in South Africa's pharmaceutical sector: balancing competition and innovation (unpublished)

Press release on the Aspen case, 14/10/2016. http://www.agcm.it/en/newsroom/press-releases/ 2339-a480-price-increases-for-cancer-drugs-up-to-1500-the-ica-imposes-a-5-million-euro-fineon-the-multinational-aspen.html

Roffe P (2014) Intellectual property chapters in free trade agreements: their significance and systemic implications. In: Drexl J, Grosse Ruse-Khan H, Nadde-Phlix S (eds) EU bilateral trade agreements and intellectual property: for better or worse? Springer, Berlin, $\mathrm{p} 17$ et seq

Ullrich H (2005) Expansionist intellectual property protection and reductionist competition rules: a TRIPS perspective. In: Maskus KE, Reichman JH (eds) International public goods and transfer of technology under a globalized intellectual property regime, pp 727-756

Ullrich H (2013) Strategic patenting by the pharmaceutical industry: towards a concept of abusive practices of protection. In: Drexl J, Lee N (eds) Pharmaceutical innovation, competition and patent law - a trilateral perspective. Edward Elgar, Cheltenham, pp 241-272

Ullrich H, Heinemann A (2007) Die Anwendung der Wettbewerbsregel auf die Verwertung von Schutzrechten und sonst geschützten Kenntnissen. In: Immenga U, Mestmäcker E-J (eds) Wettbewerbsrecht, Band I. EG/Teil 2, Kommentar zum Europäischen Kartellrecht, p 146

UNCTAD Roundtable on The Role of Competition in the Pharmaceutical Sector and its Benefits for Consumers, Geneva, 6-10 July 2015. https://unctad.org/system/files/non-official-document/ CCPB_7RC2015_RTPharma_EC_en.pdf

Open Access This chapter is licensed under the terms of the Creative Commons Attribution 4.0 International License (http://creativecommons.org/licenses/by/4.0/), which permits use, sharing, adaptation, distribution and reproduction in any medium or format, as long as you give appropriate credit to the original author(s) and the source, provide a link to the Creative Commons license and indicate if changes were made.

The images or other third party material in this chapter are included in the chapter's Creative Commons license, unless indicated otherwise in a credit line to the material. If material is not included in the chapter's Creative Commons license and your intended use is not permitted by statutory regulation or exceeds the permitted use, you will need to obtain permission directly from the copyright holder.

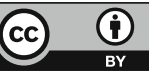

